\title{
TITLE:
}

\section{COMPOSITION OF THE FIXED SEA URCHIN COLONY ON HATAKEZIMA ISLAND, 1970}

$\operatorname{AUTHOR(S):~}$

Tokioka, Takasi

\section{CITATION:}

Tokioka, Takasi. COMPOSITION OF THE FIXED SEA URCHIN COLONY ON HATAKEZIMA ISLAND, 1970. PUBLICATIONS OF THE SETO MARINE BIOLOGICAL LABORATORY 1971, 18(6): $420-420$

\section{ISSUE DATE:}

1971-03-31

URL:

http://hdl.handle.net/2433/175649

RIGHT: 


\section{COMPOSITION OF THE FIXED SEA URCHIN COLONY ON HATAKEZIMA ISLAND, 1970}

Composition of the echinid population was examined in the fixed colony on Hatakezima Island on July 19, 1970. The water was lowest, $-3 \mathrm{~cm}$, at 12:17; it was fine, the sea was calm, and a breeze blew from the south. The ratio of the number of Echinostrephus to that of Anthocidaris (E/A) was 1.006, a little larger than in 1966-1969; this was seemingly brought about by a little decrease of Anthocidaris in the area, while the density of Echinostrephus remained as it was in 1969. For previous data see: Publ. Seto Mar. Biol. Lab., vol. 11, no. 2, 1963, pp. 415-424; ibid., vol. 14, no. 1, 1966, pp. 7-16; and ibid., vol. 17, no. 3, 1969, pp. 187-191.

Table 1. Population composition in the fixed echinid colony in July, 1970.

\begin{tabular}{l||c|c|c|c|c|c}
\hline \multicolumn{1}{c|}{ 1970, July 19 } & $\begin{array}{c}\text { Section 1 } \\
\text { (SW) }\end{array}$ & $\begin{array}{c}\text { Section 2 } \\
(\mathrm{NW})\end{array}$ & $\begin{array}{c}\text { Section 3 } \\
\text { (SE) }\end{array}$ & $\begin{array}{c}\text { Section 4 } \\
(\mathrm{NE})\end{array}$ & Total & Percent \\
\hline Anthocidaris crassispina & 71 & 86 & 120 & 55 & 332 & 45.9 \\
Echinostrephus aciculatus & 51 & 148 & 81 & 54 & 334 & 46.2 \\
Echinometra mathaei & 1 & 13 & 16 & 15 & 45 & 6.2 \\
Mespilia globulus & 5 & 3 & 1 & 2 & 11 & 1.5 \\
Hemicentrotus pulcherrimus & 1 & & & 1 & 1 & 0.1 \\
Pseudocentrotus depressus & 1 & & & & 1 & 0.1 \\
\hline
\end{tabular}

TAKasI TOKIOKA

Publ, Seto Mar, Biol. Lab., XVIII, 420, 1971. (Biological data 1) 